\title{
Visualization tools: using word clouds in teaching «Ukrainian as a Foreign Language»
}

\author{
Leshchenko T., Zhovnir M. * \\ Ukrainian Medical Stomatological Academy, Poltava, Ukraine
}

Received: 13.03 .2020

Accepted: 04.06 .2020

\begin{abstract}
The essential role of the Internet has led to an increase amount of the cutting-edge ways, methods and technologies for improving of the approaches of the present-day educational system. Therefore, it's vital for every higher educational establishment to open up for all foreign students' vast opportunities to study under the guidance of the well qualified teaching stuff. There many effective as well as exiting teaching / learning approaches that can change the way of organization and delivery of higher education in today modern society. The harnessing the most advanced information and communication technologies, particulary visualization tools, is one of such approaches. In this paper the most common and appropriate ways of using the advanced information and communication technologies for educational purposes have been described. The act that learning Web 2.0 is an emergent phenomenon was declared and explained. The main reason for using Web 2.0 educational tools, particularly visualization tools have been shown and analyzed. As mentioned above, tasks the main problems of utilizing different kinds of Web Space tools have been discussed. The others of this research have also outlined what kinds of benefits we will have after shifting your learning style from traditional to online. They tried to show the positive and negative impacts of the advanced information and communication technologies on language studying process. They paid our attention on the language training of foreigners, particularly medical students. In this response the outers have proposed algorithm of modernizing the teaching of the discipline «Ukrainian as a Foreign Language» is especially valuable, capable of harnessing the visualization tools, in particular word clouds, of the Ukrainian language teaching process to foreign students mastering the medical profession. To comply with the notion that Wordle is used for fast analysis, quick and effective remembering terms, words and active topical phrases; they suggested some exercises and tasks to do on classes.
\end{abstract}

Key words: foreign students, Ukrainian as a Foreign Language, Web 2.0 educational tools, word clouds.

\section{Засоби візуалізації: використання хмарин слів під час вивчення дисципліни «Українська мова як іноземна»}

\author{
Лещенко Т. О., Жовнір М. М. \\ Українська медична стоматологічна академія, Полтава, Україна
}

\begin{abstract}
Анотація. Посутня роль Інтернету в людському повсякденні вплинула на сучасну вітчизняну освітню галузь, окресливши проблему пошуку й раціонального впровадження ефективних шляхів й інноваційних педагогічних підходів, здатних конкурувати з традиційними методами подачі навчальної інформації, доповнювати й розширювати їхній реєстр. Провідна мета таких трансформацій - підготовка майбутніх конкурентоспроможних фахівців різних галузей, зокрема й медичної. Дидактично вмотивована імплементація різноманітних інформаційно-комунікаційних технологій, зосібна розгалуженої парадигми візуалізаційних засобів, у вишівський навчально-виховний процес має посприяти забезпеченню належного рівня подачі й моніторингу навчальної інфоормації. У цій розвідці показано й проаналізовано основні дієві способи впровадження педагогічної інноватики у вишівське викладання. Зауважено, що кожен заклад вищої освіти має виконати надскладне завдання - підготувати спеціаліста, здатного відповідати вимогам сьогодення й конкурувати 3 випускниками світових навчальних закладів у межах єдиного освітнього простору. У процесі дослідження обгрунтовано необхідність і цінність системного використання інноваційних дидактичних методів і прийомів, а також форм роботи, навчальних ресурсів, що забезпечать якісну підготовку майбутніх спеціалістів-медиків. у полі зору авторок пропонованої статті - створення тегів слів, їхнє значення під час вивчення навчальної дисципліни «Українська мова як іноземна». Авторами дослідження описано способи послуговування
\end{abstract}

Corresponding Author: Maryna Zhovnir Mikolayivna, E-mail: tetyana.57@ukr.net Ukrainian Medical Stomatological Academy, 23 Shevchenko Str., Poltava, Ukraine.

Відповідальний автор: Марина Жовнір Миколаївна, E-mail: m.zhownir@gmail.com

Української медичної стоматологічної академії, Україна, м. Полтава, вул. Шевченка, 23. 
можливостями й інструментарієм WordArt.com для створення тематичних хмарин слів, фахових термінів, термінологічних словосполучень і фраз. Крім цього, у статті подано систему вправ і завдань, які можна використовувати на практичному занятті з дисципліни «Українська мова як іноземна» (III курс, спеціальність «Медицина»). Окреслено пріоритетні напрями інформатизації вищої освіти в нашій державі, визначено шляхи подальших досліджень у цьому руслі.

Ключові слова: іноземні студенти, Українська мова як іноземна, технології Web 2.0, хмарини слів.

\title{
Инструменты визуализации: использование облака слов при изучении дисциплины «Украинский язык как иностранный»
}

\author{
Лещенко Т. А., Жовнир М. Н. \\ Украинская медицинская стоматологическая академия, Полтава, Украина
}

\begin{abstract}
Аннотация. Возрастающая роль Интернета в жизни человека влияет на современную отечественную образовательную сферу, определяя проблему поиска и рационального внедрения эффективных путей и инновационных педагогических подходов, способных конкурировать с традиционными методами подачи учебной информации, дополнять и расширять их реестр. Основная цель таких трансформаций - подготовка будущих конкурентоспособных специалистов различных отраслей, в том числе и медицинской. Дидактически обоснованная имплементация современных информационно-коммуникационных технологий, развитой парадигмы дидактических средств визуализации ученого материала в вузовский учебно-воспитательный процесс способствует обеспечению надлежащего уровня подачи учебной инфоормации и мониторинга знаний студентов, в частности иностранцев. В этом исследовании показаны и проанализированы основные способы внедрения педагогической инноватики в вузы. Отмечено то, что высшие учебные заведения должны подготовить специалиста, способного конкурировать с выпускниками мировых учебных заведений в рамках единого образовательного пространства. В процессе исследования обосновано необходимость и ценность системного использования инновационных дидактических методов и приемов, форм работы, учебных ресурсов, которые могут обеспечить качественную подготовку будущих специалистов-медиков. В поле зрения авторов предлагаемой статьи - создание тегов слов, их значение при изучении учебной дисциплины «Украинский язык как иностранный». Авторами исследования описано возможные способы использования инструментария WordArt.com для создания тематических облаков слов, профессиональных терминов, терминологических словосочетаний и фраз. Кроме этого, в статье представлено систему упражнений и заданий, которые можно использовать на практическом занятии по дисциплине «Украинский язык как иностранный» (III курс, специальность «Медицина»). Определены приоритетные направления инсорматизации высшего образования в нашей стране, описаны пути дальнейших исследований в этом направлении.
\end{abstract}

Ключевые слова: иностранные студенты, Украинский язык как иностранный, технологии Web 2.0, теги слов.

\section{Introduction}

Foreign students who enter Ukrainian medical higher educational establishments to get a Diploma in Medicine or Dentistry want to receive an appropriate training in these specialties. The above-mentioned specialties are open to all foreigners who have completed secondary schools in their countries. For now, the specialty in highest demand among youth from Morocco, Syria, Jordan, Iran, Iraq, Lebanon, Palestine, Ghana, Nigeria, Pakistan, India, etc. is medical. Thus, we have a lot of students mastering the medical occupations from these countries in Ukraine. Furthermore, their number is constantly growing. «Foreign students seek to speak Ukrainian to study the educational material included in curricular and to adjust the realities of Ukrainian way of life» [7].

«Health is the most important thing for people» [6]. So, future doctors must try to do their best to keep it and to cure patients. In this response Ukrainian higher educational establishments must open up for all foreign students vast opportunities to study under the guidance of the well qualified teaching stuff. We also must seize the possibility to provide them with all necessity support. In order to realize stated purposes hearts and universities teachers are committed to providing appropriate learning capacity for all students to help them attend all-round development and professional growth. That's why we need to modernize the present educational system in our country. Firstly, we should to shift focus of the traditional teaching to the reformed ones. These modifications will require rapid didactic changes and profound transformations, mostly gradual implementation of innovative didactic models and new educational methods. 
Nowadays, there are sufficient flexibility in teaching. «Pedagogical innovations are focused on searching new and adequate mechanism to actualize special potential» [4]. The same thoughts we can find in other research $[8,12]$. Traditional style of teaching and learning is under the favorable conditions after the innovation of Web 2.0. Computer and Internet use is a growing phenomenon. Expense use of the cutting-edge computer resources complements and enhances teaching in traditional classrooms. Such an approach, in our view, is a prime way of the improving of the approaches of the present-day educational system.

This research aims to explore the need to change the traditional style of teaching and learning languages, in particular "Ukrainian Language as a Foreign», after the innovation of Web 2.0. In this paper we want to concentrate on the language training of foreigners, particularly medical students. For us, the algorithm of modernizing the teaching of the discipline "Ukrainian as a Foreign Language» is especially valuable, capable of harnessing the most advanced information and communication technologies of the Ukrainian language teaching process to foreign students mastering the medical profession.

The main objectives of this research are to recognize the impact of Web Space tools in learning and education generally, to discover the possibilities for the use of Wordle as a kind of data visualization tool by higher education teachers in Ukraine, to analyze the benefits of such pedagogical innovations and to determine whether the traditional learning methods need to be changed in the era of current Web technologies?

Taking into consideration the motivation for this research, the aims and the objectives, the accentuated the following research questions:

1) How do we usually use the most advanced information and communication technologies for educational purposes?

2) What is your main reason for using Web 2.0 educational tools, particularly visualization tools?

3) What are the main problems of utilizing different kinds of Web Space tools?

4) What kinds of benefits will we have after shifting your learning style from traditional to online?

5) What are the positive and negative impacts of the advanced information and communication technologies on education?

In the last two decades, ICT has been recognized as the important tool to enchase learning and teaching all around the world. The issue of ICT establishment as a learning effective instrument is outlined in the studies of Ukrainian researchers. The methodological base of modern technologies in education is at the stage of active creation, and detailed exploration of the phenomenon of ICT is devoted to scientific exploration of both world and Ukrainian researchers (Voronina, 2013; Betsko, 2012; Bihych; 2012; Carvalho, \& Aguiar, 2014; Cebeci, 2006; Clothey, \& Schmitt, 2008; Grytsyk, 2015; Danyliuk, 2014; Degtyaryova, 2019; Dragunova, 2014; Epifantseva, 2019; Kardashova, 2015; Madzihon, 2002; Matviiv-Lozynska, 2015; Naydenova, \& Ponomarenko, 2018; Nikolaiev, 2003; Susoev, 2009; Strashko, 2015; Stupina, 2006; Hahina, 2014, Shekhavtsova, \& Protopopova, 2019, ets.).

The research publications of Ukrainian and foreign scientists gave careful consideration to the question of harnessing and efficient implementation of visualization tools or their elements into the educational process on different levels of education (Aman, \& Lutvunenko, 2016, Vlasova, 2018, Bezkrovna, 2018, Dron, 2018, Clement, \& Plaisant, \& Vuillemot, 2008, Pozdnjakova, \& Tumchuna, 2019, Ramsden, \& Bate, McNaught, \& Paul Lam, 2010, Sinclair, \& Cardew-Hall, 2008, Feinberg, 2009, ets.).

\section{Materials and Methods}

The research was performed within the anthropocentric scientific paradigm. Basic - general linguistic method of scientific description. The paper appeals to the generalization, systematization, classification, interpretation of linguistic scientific fact. The descriptive-analytical method was used to analyze and systematize the features of ICT implementation in the educational process; comparison method - to compare innovative and traditional educational methods and techniques. Also, special linguistic methods and techniques, including discourse analysis, have been appealed. 


\section{Results}

Nowadays, educational innovations are actively discussed among the number of specialists around the world. Web Space tools are becoming very popular in our modern society. Information and communication technologies (ICT) are transforming peoples' ways of lives. For example, the harnessing of these technologies has already changed the manner in which businesses are conducted, people meet each other, leisure time is spent, information and services are accessed, entertainment and communication are occurring across societies and continents, etc.

Web 2.0 is a widely refereed term which is commonly associated with applications on the Internet which facilitate interactive information sharing, cooperation and engagement in learning on the World Wide Web. It's generally known, that Web 2.0 tools include wikis, web applications, social-networking sites, blogs, hosted services and many others tools which give its users the ability to communicate with others in a virtual context. It is particularly significant that many people are attracted to such way of collaboration and communication.

Recently, on-line education systems have become widespread tools adopted by both historical and newly founded educational institutions. E-learning and e-teaching are new contexts for education through which large amounts of information are generated and available to user's world-wide. A large portion of the available information takes the form of free text without the structure required for automated knowledge retrieval. Learning analytics provides valuable support for teachers and students to understand learning habits and to obtain rich information about learning and teaching processes.

Height school management processes also benefit from opportunities provided by ICT. For example, many online tools are increasingly available for use in educational settings. It's evident that, learning Web 2.0 is an emergent phenomenon. This process is fostered and maintained by bottom-up take up of social computing in educational contexts. Although modern Technologies have huge potential in teaching and learning foreign languages, inter alia «Ukrainian Language as a Foreign». As online learning spreads and becomes pervasive, the need for tools that monitor students' participation in online courses and measure knowledge and skills development has greatly increased.

Speaking about the background, results, evident progress and obvious benefits of these researches, we should note that they have already explained the essence of ICT, have defined the term and have successfully analyzed its basic peculiarities. In addition to above-mentioned, scientists have already described in detail the specific ways of practical implementation ICT to the educational process.

Despite these evident achievements, teaching standards for the higher educational institutions still faces challenges in bringing on board key points of efficient up taking of ICT tools. Moreover, the effective ways and date visualization techniques, which could be used to help achieve the significant improvement of the teaching in the aria of languages, in particular curriculum language training of foreign students mastering the medical occupations, must be studied and investigated as soon as feasible. These facts confirm the relevance, timeliness and practical value and of the proposed article.

\section{Discussion}

In today's society, diverse educational approaches for teaching and learning are exist. From now specific Internet tools are actively used for educational purposes, notably for groups and mini-groups training as well as for individual studying. It's also commonly used for facilitating search of the required educational information within the whole world informational content rather than in separate informational system. So, thus if someone wants to learn something new, aims to improve language skills, or seeks be keen on picking up future profession as well as to participate in virtual projects, competitions, seminars, webinars, workshops, educational programs, summer schools, camps, and other activities, now is the high time to educational innovation and bold experiments. Meanwhile, the total application of ICTs has already changed the way of organization and delivery of higher education. Guided by the importance of reorienting education to the use of information and communication technologies, it also focuses on multimedia resources for creating quizzes, didactic games and tests. Such creative pursuits complement the developed theoretical and methodological base of new forms and methods of teaching, gradually form an unconventional approach to the learning process, prevent the transformation of teaching discipline into an automatic, devoid of elements of creativity mechanical work with actual material. 
In the new past years, there have been fast-growing online educational courses, programs and Internet recourses. The advanced ICT have been successfully up took by many colleges, universities, academies and other types of higher schools. With the increasing popularization of computer visualization technologies, the way of classroom teaching has also changed from plain lectures to multimedia presentations. From our point of view, with the extensive use of different visualization tools, teaching as well as learning can be completely improved, foster and contribute for successful Ukrainian language learning by foreign students mastering the medical occupations in and out of classrooms.

It seems that many students have a positive attitude toward the special style of teaching, which includes the diversity of visualization instruments, programs and services. Probably, they would like teaching routine to be changed by adopting visualization tools. Our training experience has shown that majority of the students that such way of teaching should change their attitude towards language education in our country and, probably, it would enhance their motivation, which could only benefit them.

Scholars consider visualization as «The conversion of information to a symbolic representation of a particular idea, concept, or data object» [2]. Visualization can be also defined as «The process of transforming data, information, and knowledge into graphic symbolic presentations. T. Barret proposed to define data visualization tools as «Devices which use for representing information in the form of charts, maps, tag clouds, animation or any graphical means that make content easier to understand» [1]. M. Friendly mentioned that «Data visualization serves as a way to communicate information clearly and effectively through visual representation. These tools can help to make the understanding of complex thing easier because they provide data in multi aspects incorporating visual, textual animated input and etc» [9].

In our modern age, there are many services, which can be used for instructional purposes. Scientist K. Degtyaryova's research indicate that «New online educational programs and services for creating special tasks, fragments of lessons, quizzes, crosswords, such as (http://puzzlecup.com/crossword-rul, https://flippity.net/, https://app.wizer.me/editor/Wf33rEYAq62B), word clouds (https://wordcloud.pro, https://wordart.com/), ets. are continually providing and maintaining at present days. These tools and innovations foster the creation of current educational facilities and its rational utilization in multimedia presentations» [3].

For creating cloud of words the following services can also be used: www.tagxedo.com www.wordle.net, www.worditout.com, www.tagcrowd.com, www.wordart.com, www.wordcloud.pro/en, www.wordsift.orgб, ets. The process of creating the picture won't take long. Furthermore, it's fun, visual and entertaining. The same ideas we found in other papers on this theme: "There are some tools on the internet to provide such word clouds such as Wordsift, Tagxedo, Tagul, Tag Crowd and Wordle. Wordle, created by IBM developer Jonathan Feinberg in 2009, is one of the most popular tools on the internet for generating word clouds» [8]. Similarly, all definitions relating to visualization software are mutually complementary.

T. Pozdnjakova, V. Tumchuna, N. Tumchuna, for example, analyzed the available service Wordart.com. This service is commonly used for creating cloud of words. In their research «The ideas of creating word clouds in biology lessons» they examined the benefits of using cloud of words and this educational program in the educational process, aimed at developing cognitive and emotional skills, highlighted computer and mobile visualization [7].

A word cloud is a special visualization of text. In this text or in the one passage of the document more frequently used words are effectively highlighted by occupying more prominence in the representation. T. Pozdnjakova, V. Tumchuna, N. Tumchuna have defined this phenomenon: «Cloud of words is visualization of the word list, categories, notes, and placards on the same space» [7]. In their scientific researches they have also concluded, that «Cloud of words is techniques of the graphic information systematization» [7]. In that connection, we share the opinion of these educators. Additionally, it is necessary to be noted that visualization software, in particular Wordle, is commonly used in the classroom to impact knowledge and create awareness on the students. The mentioned above types of activities encourage students to react to topics or concepts and produce their own understanding based on that reaction.

In this respond M. Mbodila and M. Kikunga have noted: «With the help of tools such as visualization and simulation technologies, virtual learning environments, e-learning environment and visualization software, large number of ICT undergraduate students can start to observe phenomena using remote instruments, and make valuable connections in the classroom within structures» [5]. 
By means of cloud of words the list of terms, definitions, word and word combination can be visualized. The use of word cloud fostering better memorization, more convenient information perception, understanding of key concepts, terms, facts, phenomenon, phrases, expressions, etc. Colored word clouds hold the attention of students and stimulate their memory. Apart of all these benefits, it helps them to consternate on the fundamentals.

Visualization software can also help students to develop critical-thinking, some educational problemsolving, causal link between words, and particularly medical lexemes (for foreign medical students). The important thing is that word cloud contains visualize information and semantic context.

Specifically, we would like to demonstrate that Wordle (word clouds, word tags) can be used as:

1) The way how to diversify approach to educating;

2) The opportunity how the most frequently used words, terms and phrases can be effectively highlighted by occupying more prominence in the representation;

3) The suggestions of more personalized learning opportunities that are tailored to their learners' individual needs and preferences, and thus improve quality and efficiency instruments for preliminary analysis and for validation of previous findings;

4) The more effective method to memorize and recall educational information faster and better;

5) The technique which is often used to increase motivation for studying, including learning languages, etc.

The algorithm of teaching visualization of the discipline «Ukrainian Language as a Foreign» is especially valuable for us. So, we propose several word tags on the topics taught in Ukrainian medical higher educational institutions. Further, we have to note that all following above topics are consistent with the current educational programs and proprieties.

For example, the term continuum for the topic «The Doctor - Patient with the symptoms of the cardiovascular system disease communication» (specialty «Medicine, the $3^{\text {rd }}$ year of students) can be presented in the shown bellow way (Fig. 1).

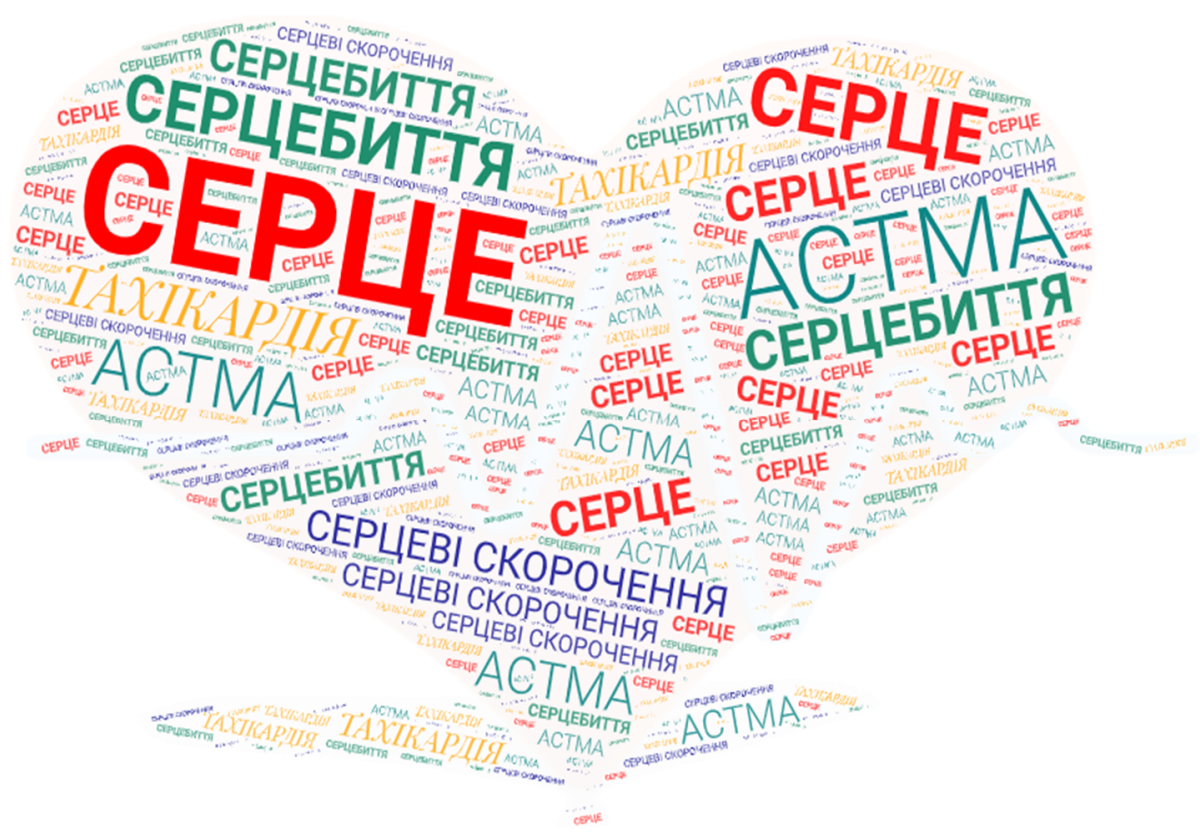

Fig. 1. The Word Cloud «Cardiovascular system»

In accordance to the curriculum and current educational program in Ukrainian as a Foreign Language foreign medical students study respiratory organs, primarily terms denoting its structural elements, basic features and functionality. Furthermore, the common signs of the respiratory diseases and different pathological conditions must de memorized. And thus, the terminological spectrum in the subject matter (specialty «Medicine», the $3^{\text {rd }}$ year of students) can be presented in the shown bellow way (Fig. 2). 


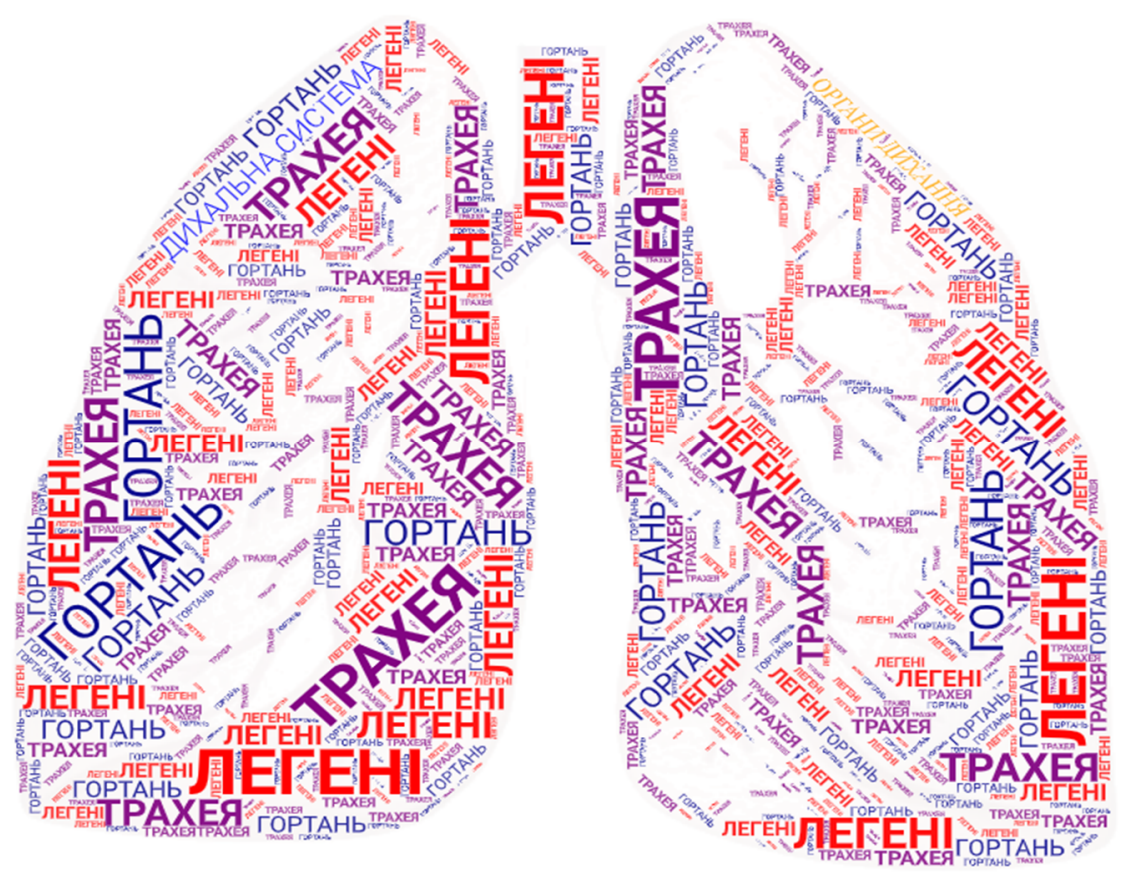

Fig. 2. The Word Cloud «Respiratory system»

In this response the important fact is that, students are engaged in the learning process and motivated by making word clouds which foster them to memorize and to articulate a preference for doing things creatively rather than writing usual exercises, reading texts or listening to teacher talking. With this, most language teachers consider learning with using visualization tools as one of the effective ways for students to learn Ukrainian language by foreign students.

To comply with the notion that Wordle is used for fast analysis, quick and effective remembering terms, words and active topical phrases; we would like to suggest some exercises and tasks to do on classes. The medical terms (topic "Gastroenterology department» specialty «Medicine», the $3^{\text {rd }}$ year students) of these tasks can be fed into Wordle individually and word clouds resulted. These manipulations with Wordle offer innovative challenges and opportunities for both teachers and students.

№ 1. Читайте слова. Вивчіmь нові слова / Read the words. Learn new words.

\begin{tabular}{|l|l|}
\hline Їжа & food \\
травлення & digestion \\
стравохід & esophagus \\
травна система & digestive system \\
травна залоза & digestive gland \\
ротова порожнина & mouth cavity \\
глотка & throat, pharynx \\
шлунок & stomach \\
кишечник (тонкий, товстий) & intestine (small, large) \\
слина & saliva \\
слинні залози & salivary glands \\
печінка & liver \\
дванадцятипала кишка & duodenal intestine \\
черевна порожнина & abdominal cavity \\
жовч & gall \\
жовчний міхур & gall bladder \\
підшлункова залоза & pancreatic \\
шлунковий сік & gastric juice \\
\hline
\end{tabular}


№2.Подивіться на малюнок. Прочитайте назви органів травної системи. Знайдіть їх на малюнку. Оберіть 5 термінів, створіть хмарину слів у формі печінки / Look at the picture. Read names of the organs of the digestive system. Find them in the picture. Choose 5 terms and create word cloud in the shape of liver.

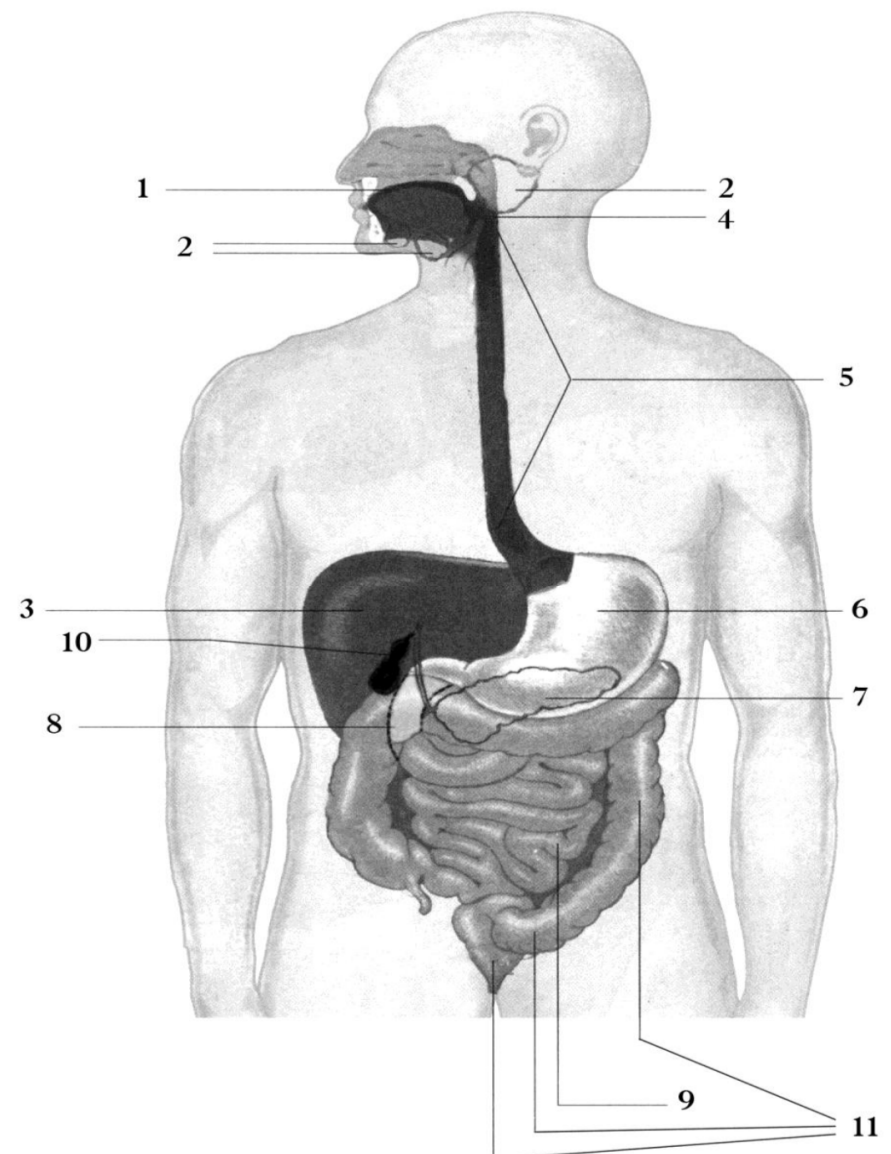

Довідка: печінка, кишечник шлунок, слинні залози, жовчний міхур, товста кишка, тонка кишка, ротова порожнина, стравохід, дванадиятипала кишка, підшлункова залоза.

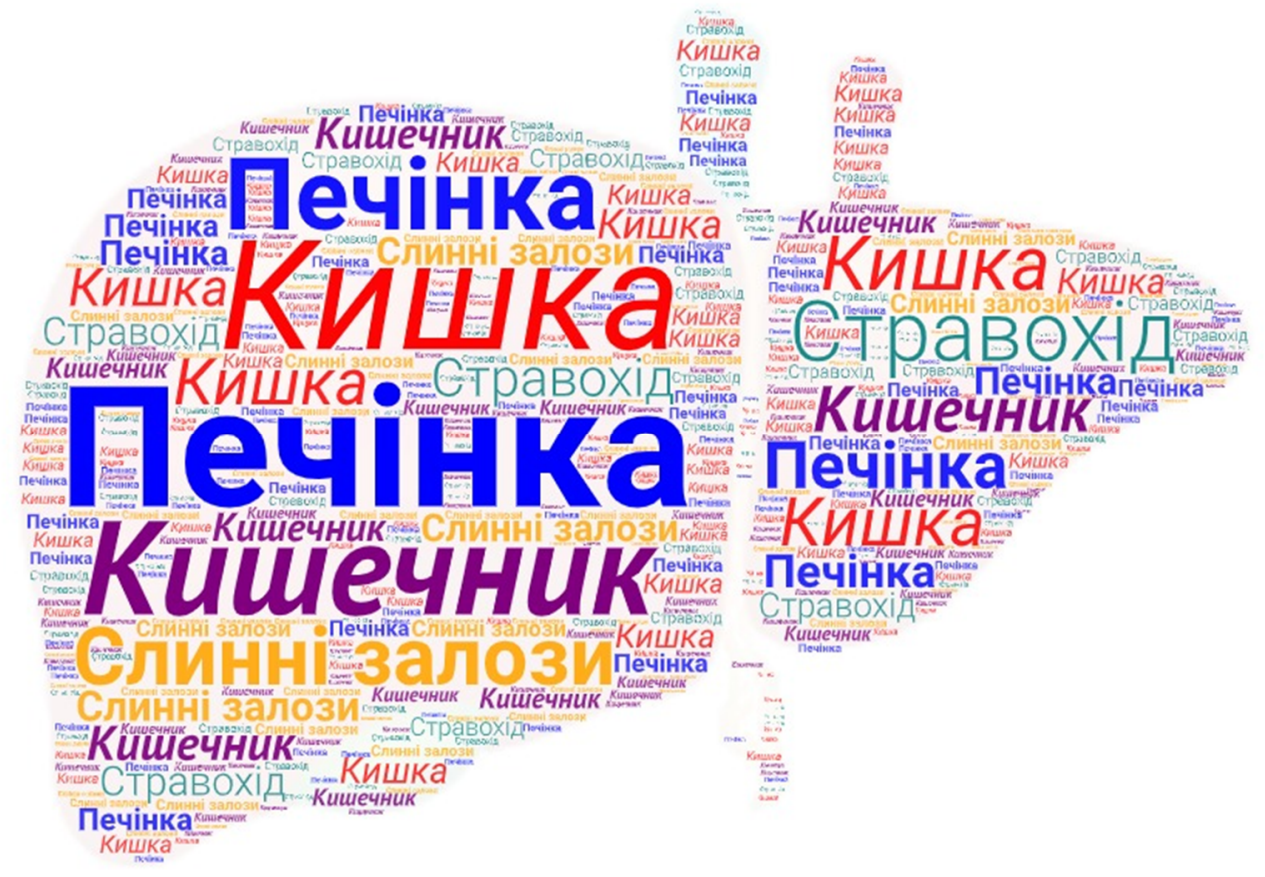

Fig. 3. The Word Cloud «The digestive organs» 
№3. Читайте текст. Перекладіть підкреслені слова англійською мовою. Створіть хмарину слів, використавши 5 словосполучень на позначення органів травної системи людини / Read the text. Translate underlined words into English. Choose 5 terms / terminological phrases and create word cloud in any shape.

\section{ТРАВНА СИСТЕМА ЛЮДИНИ}

Digestive system consists of digestive canal and digestive gland. The digestive canal consists of oral cavity, pharynx, esophagus, stomach, intestine. Mucus glands, gastric glands, intestinal glands, liver and pancreas are the main digestive tract glands.

Food first enters the oral cavity. In the oral cavity, the food is chewed and chemically treated. There is always saliva in the oral cavity. Saliva is formed in the salivary glands. Due to saliva, the food enters the throat, and then into the esophagus. Then the food enters the stomach. In the stomach, the gastric glands secrete gastric juice. Enzymes accelerate the digestive process. The food is converted into a homogeneous mass in the stomach. The digestion process lasts from 1 to 4 hours. From the stomach, the food enters the small intestine.

The liver and pancreas emit juices in the duodenum. The liver is the largest digestive gland. Its weight is 1,5 kilograms. The liver constantly secretes bile. The bile is a liquid of dark yellow color. It promotes the splitting of fats.

From the liver the bile enters the gall bladder, and then - into the intestine. The digestive process ends in the small intestine. In the small intestine, nutrients are absorbed into the blood and lymph, and then absorbed into the tissues of the body.
Травна система складається 3 травного каналу i травної залози. Травний канал складається 3 ротової порожнини, глотки, стравоходу, шлунка, кишечника. Слинні залози, шлункові залози, залози кишечника, печінки та підшлункова залоза - це основні залози травлення.

Їжа спочатку потрапляе в ротову порожнину. у ротовій порожнині їжа пережовується і піддається хімічній обробці. у ротовій порожнині завжди $є$ слина. Слина утворюється в слинних залозах. Завдяки слині їжа потрапляє в глотку, а потім потрапляє у стравохід. Потім їжа потрапляє у шлунок. У шлунку шлункові залози виділяють шлунковий сік. Ферменти прискорюють процес травлення. У шлунку їжа перетворюється на однорідну масу. Процес травлення триває 1 - 4 години. Із шлунка їжа потрапляє в тонкий кишечник.

Печінка та підшлункова залоза виділяють соки в дванадцятипалу кишку. Печінка - це найбільша травна залоза. Ї̈̈ вага - 1, 5 кілограми. Печінка постійно виділяє жовч. Жовч - це рідина темно-жовтого кольору. Вона сприяє розщепленню жирів.

Із печінки жовч потрапляє в жовчний міхур, а потім - у кишечник. Процес травлення закінчується в тонкому кишечнику. У тонкому кишечнику поживні речовини всмоктуються в кров і лiмфу, а потім - у тканини організму. 


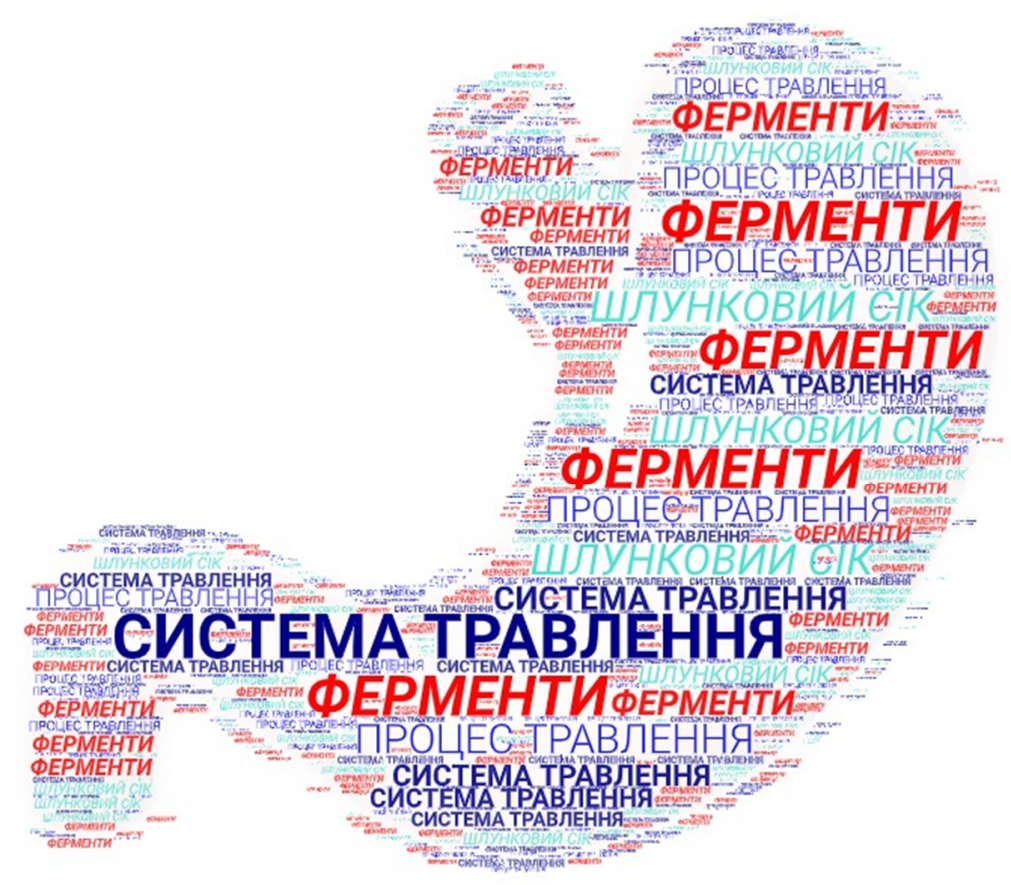

Fig. 4. The Word Cloud «The digestive process»

№3. Перекладіть українською мовою / Translate into Ukrainian.

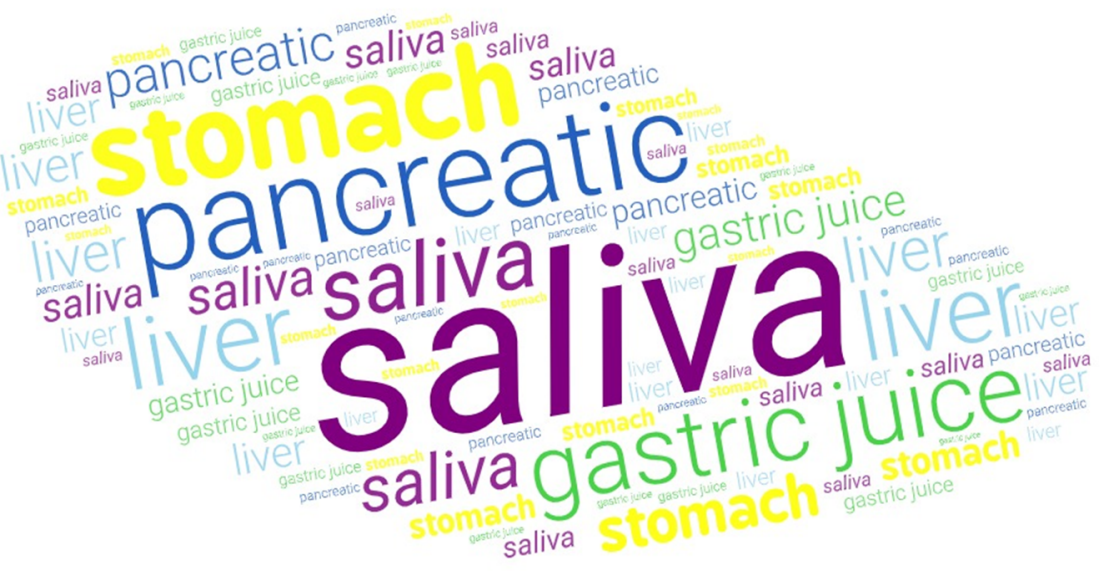

Fig. 5. The Word Cloud «The digestive process»

№4. Дайте визначення термінів. Утворіть з цими словами речення і створіть хмарину слів / Give definitions to the words. Make up sentences using the following verbs. Create word cloud in any shape.

Печінка, підшлункова залоза, жовч, ротова порожнина, процес травлення.

№ 10. Відновіть інформацію другого абзацу. Використовуйте опорні слова / Restore the information of the 2th paragraph by the basic words and word combinations.

Їжа, ротова порожнина, хімічна обробка, слина, глотка, стравохід, шлунок, шлунковий сік, ферменти, процес травлення, 1 - 4 години, тонкий кишечник.

№11. Читайте пункт «Довідка». Чого немає на поданих нижче малюнках? Обведіть кружечком зайві слова. Створіть хмарину слів / Read the «Help» item. Circle the unnecessary words. Create word cloud in any shape.

Довідка: слина, слинні залози, кров, ротова порожнина, череп, печінка, підшлункова залоза, нирки, серие, стравохід, глотка, ферменти, жовч, вода. 
1)

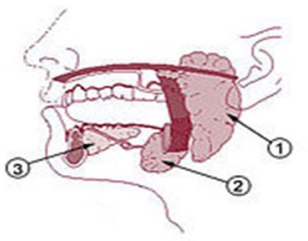

4)

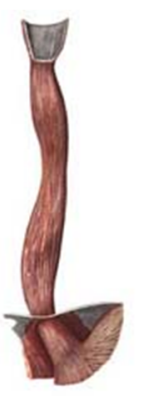

2)

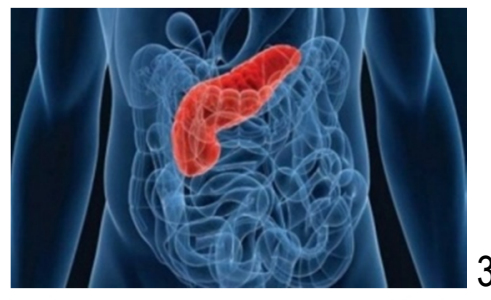

3)
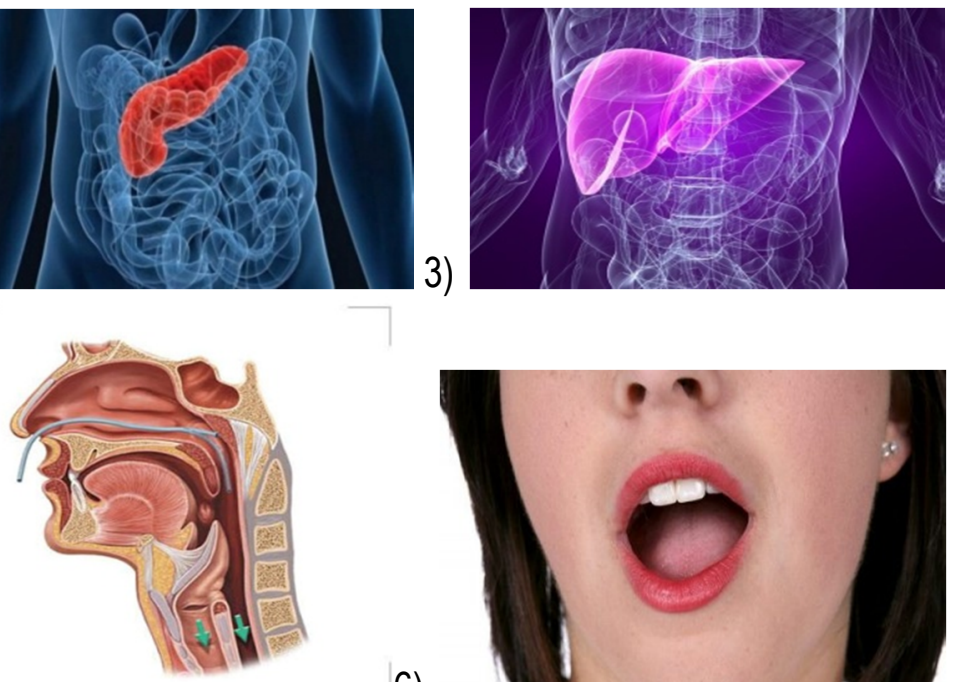

6)

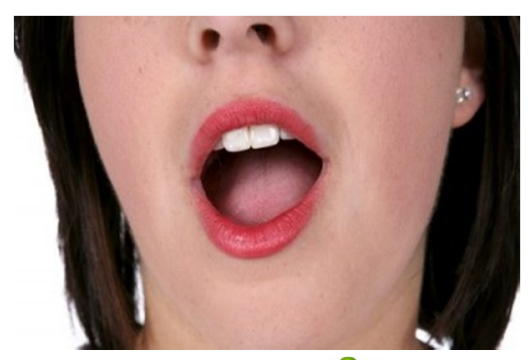

5)

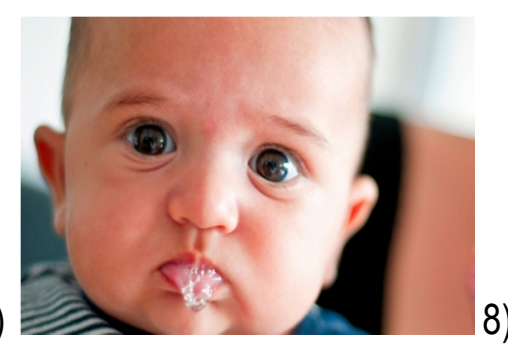

8)

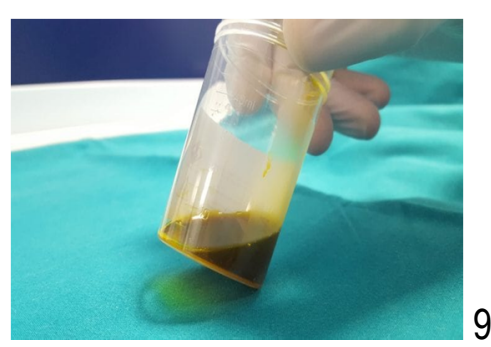

9)

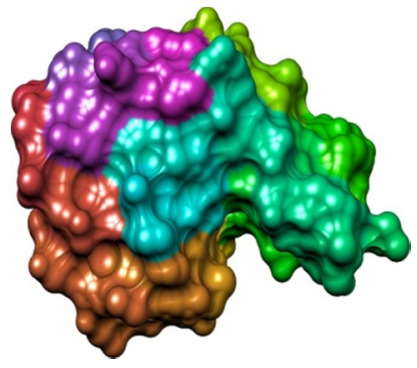

№12. Читайте діалог в особах. Подивіться на малюнки. На малюнках зображено УзД (ультразвукову діагностику) та ФСГ (фріброгастроскопію). Поясніть значення підкресленого слова. Створіть вдома хмарину слів із новими термінами / Dialogue. Read the dialogue in person. The pictures depict ultrasound diagnostics and fibrogastroscopy. Explain the meaning of the underlined word. Create at home word cloud using new terms.

- Добрий день! На що ви скаржитесь?

- Мене постійно нудить.

- Щось болить?

- Ось тут. Болить шлунок.

- Коли починає боліти?

- Болить постійно.

- Біль ниючий?

- Так. Постійний ниючий біль. Нудота. Особливо після того, як поїм.

- Ви їсте гостру, жирну їжу?

- Інколи. Люблю бургери і газовані напої.

- Уночі біль вас турбує?

- Іноді болить і вночі.

- Відчуваєте дискомфорт у шлунку?

- Так. Постійно!

- У вас регулярні випорожнення?

- Лікарю, іноді не можу сходити в туалет кілька днів.

- Коли ви востаннє робили УЗД (ультразвукову діагностику)?

- Навіть не пам'ятаю?

- А ФСГ (фіброгастроскопію)?

- Давно.

- Я раджу вам додаткове обстеження. Щоб з'ясувати діагноз, потрібно здати аналізи і зробити УЗД (ультразвукову діагностику) черевної порожнини та ФСГ (фріброгастроскопію). 
- Дякую, лікарю.

- Чекаю вас у понеділок з 8:00 до 17:00!

- Дякую. До понеділка.

- До побачення.

\section{$\checkmark$ Conclusion}

So, just summing things up, we should point out that one of the most important tasks of the educational system today is to introduce and continue to make steady progress on the implementation educational technologies that could facilitate the formation of a creative and active personality, able to meet the challenges and to achieve the desired goals. The above highlights the importance of the development and implementation of different educational approaches to the realization of the basic educational tasks, focused at the development of students' creative activities and their inner potential.

The harnessing the most advanced information and communication technologies is one of such approaches. It is particularly relevant and important for the Ukrainian language teaching process to foreign students mastering the medical profession. Nowadays the language teachers have to understand the efficient pedagogical technologies. They should use in teaching Ukrainian as a Foreign Language educational the information and digital technologies effectively.

The effective and harnessing incorporation of visualization tools into the educational process, including studying Ukrainian, will help foreign students gain the necessary lexical and partial grammatical knowledge of the Ukrainian language. Teachers can use Wordle in pre-listening stage providing word clouds before and during speaking. It can be beneficial.

The visualization allow students to grasp the common themes in the text, and sometimes even to find out main differences between sets of responses. It also helps them to consternate on the fundamentals and quickly visualize some general patterns in text / exercises. In other words, they would be benefited from providing vocabulary and other important educational information in this way.

In addition, the advanced information and communication technologies in general, and word clouds in particular, give foreign students better learning opportunities to enhance their educational performance. They would prefer to find better ways of learning by changing their learning styles and engaging in educational environment that has more dynamic and creative.

Our results do not cover all aspects of the researched issue. Today's educators succeed in mastering educational visualization resources they use in the class. At the same time there are still many unexplored areas of this problem that we need to consider very carefully. Further research should be devoted to the new possibilities of the educational space effective modernization, its advantages and disadvantages as well.

\section{References}

1. Barret, T. (2010). Forty-five Interesting Ways to Use Wordle in the Classroom. URL: http://www.slideshare.net/ boazchoi/fortyfive-interesting-ways-to-use-wordle-in-theclassroom (accessed 2020 May 01).

2. Brown, C.A. Brown, Banas, J.R. (2010), Open Source Visualization Tools to Enhance Reading Comprehension and Concept Attainment. URL: https://members.aect.org/pdf/Proceedings/proceedings10/2010//10_07.pdf (accessed 2020 May 07).

3. Dehtiarova, K.V. (2018). Computer multimedia presentation in the system of teaching aids in the Ukrainian language as a foreign language [Komp'yuterna mul'timedi jna prezentaczi'ya u sistemi' zasobi’v navchannya z ukrayins'koyi movi yak inozemnoyi]. Current issues of linguistics, professional language didactics, psychology and pedagogy of higher education: collection. Articles IV International. scientific-practical conf. (Poltava, November 7-8, 2019) (Aktual'ni' pitannya li'ngvi’stiki, profesi jnoyi li’ngvodidaktiki, psikhologi yi i’ pedagogi ki vishhoyi shkoli : zb. statej IV Mi zhnar. nauk.-prakt. konf. (m. Poltava, 7-8 listopada 2019 r.)) pp. 101-107 [in Ukrainian]

4. Zhovnir, M.M., Aslamova M.V. (2018). Pedagogical innovates in medical high school: implementation of coaching technology [Pedagogi'chna i'nnovatika v medichnomu vishi': do pitannya vprovadzhennya kouching-tekhnologi'yi] Young scientists [Molodij vcheniij], 1, 309-312. [in Ukrainian].

5. Mbodila, M., Kikunda, M. (2019). Effective teaching and Learning Approach use of visualization software tools in the classroom. URL: https://www.academia.edu/8803911/ Effective_Teaching_and _Learning_Approach_use_of_visualization_ software_tools_in_the_classroom (accessed 2020 May 04).

6. Leshchenko, T., Zhovnir, M. (2018). Health vs. Disease in the Context of Verbalization of the Axiological Picture of the World of a Modern Doctor (Zdorovia vs. khvoroba v konteksti slovesnoi reprezentatsii tsinnisnoi kartyny svitu suchasnoho likaria). Psycholinguistics (Psykholinhvistyka), 24 (2), 163-180. [in Ukrainian]. 
7. Leshchenko, T.O., Zhovnir, M.M. (2020). The use of Kahoot to study ukrainian language as foreign in medical higher educational institutions [Vykorystannia elektronnoho servisu Kahoot pid chas vyvchennia predmeta «Ukrainska mova yak inozemna» u vyshchomu medychnomu zakladi osvity]. Modern medical education: methodology, theory, practice: materials scientific conf. with international participation (Poltava, March 19, 2020) [Suchasna medychna osvita: metodolohiia, teoriia, praktyka : materialy Vseukr. navch.-nauk. konf. z mizhnar. uchastiu (m. Poltava, 19 bereznia 2020 r.)], pp.124-127. [in Ukrainian].

8. Pysanko, M. (2019). Moodle as a means of teaching prospective interpreters in e-learning to enhance discovery in English. URL: https://journal.iitta.gov.ua/index.php/itt/article/view/2644 (accessed 4 April 2020). [in Ukrainian].

9. Pozdnyakova, T., Timchina, N., Timchina, V. (2019). Creation and ideas of using word clouds on biology lessons [Stvorennya ta i'deyi vikoristannya khmarin sli'v na urokakh bi' ologi yi] New Pedagogical Thought [Nova pedagogi chna dumka], 1 (97), 4954. [in Ukrainian]

10. Tafazoli, D. (2014). Wordling using word clouds in teaching English language. Professional communication and translation studies, 7 (1-2), 167-172.

11. Friendly, M. (2008). A Brief History of Data Visualization. URL: https://www.researchgate.net/ publication/ 226400313 A_Brief_History_of_Data_Visualization (accessed 2020 May 01).

12. Chaik, T. (2019). Online tools for assessment of foreign language competence of students of higher educational tasks: foreign experience. URL: https://journal.iitta.gov.ua/index.php/itt/article/view/2501 (accessed 2020 May 01]). [in Ukrainian]

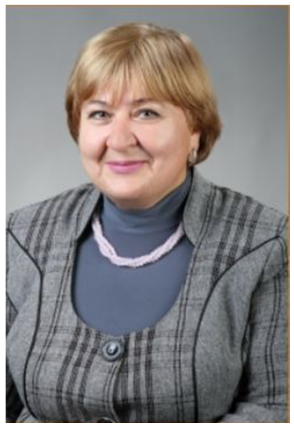

Лещенко Тетяна Олександрівна,

кандидат філологічних наук, доцент, завідувачка кафеедри українознавства

та гуманітарної підготовки

Української медичної стоматологічної академії

Україна, м. Полтава, вул. Шевченка, 23

E-mail: tetyana.57@ukr.net

\section{Leshchenko Tetyana Oleksandrivna,}

Ph.D. in Philology, Associate Professor,

Heard of the Department of Ukrainian Studies and Humanitarian Training

Ukrainian Medical Stomatological Academy

23 Shevchenko Str., Poltava, Ukraine

E-mail: tetyana.57@ukr.net

ORCID: 0000-0003-4682-3734

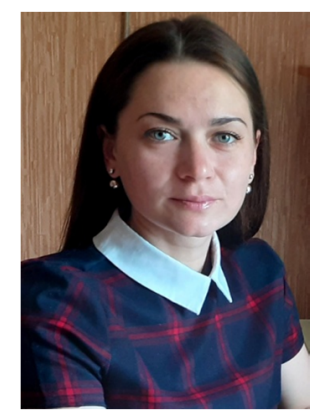

Жовнір Марина Миколаївна,

кандидат філологічних наук, викладач кафедри українознавства

та гуманітарної підготовки

Української медичної стоматологічної академії

Україна, м. Полтава, вул. Шевченка, 23

E-mail: m.zhownir@gmail.com

\section{Zhovnir Maryna Mikolayivna,}

Ph.D. in Philology, Lecture of the Department of Ukrainian Studies and Humanitarian Training

Ukrainian Medical Stomatological Academy

23 Shevchenko Str., Poltava, Ukraine

E-mail: tetyana.57@ukr.net

ORCID: 0000-0001-8498-9802

\section{Citation (APA):}

Leshchenko, T., Zhovnir, M. (2020). Visualization tools: using word clouds in teaching «Ukrainian as a Foreign Language». Engineering and Educational Technologies, 8 (2), 79-91. doi: https://doi.org/10.30929/2307-9770.2020.08.02.07

\section{Цитування (ДСТУ 8302:2015):}

Лещенко Т. О., Жовнір М. М. Засоби візуалізації: використання хмарин слів під час вивчення дисципліни «Українська мова як іноземна» / Інженерні та освітні технології. 2020. Т. 8. № 2. С. 79-91. doi: https://doi.org/10.30929/2307-9770.2020.08.02.07

Обсяг статmі: сторінок-13 ; умовних друк. аркушів - 1,883. 